\title{
The effect of the PPARgamma ligand rosiglitazone on energy balance regulation
}

Citation for published version (APA):

Joosen, A. M. C. P., Bakker, A. H. F., Gering, M. J., \& Westerterp, K. R. (2006). The effect of the PPARgamma ligand rosiglitazone on energy balance regulation. Diabetes-metabolism Research and Reviews, 22(3), 204-210. https://doi.org/10.1002/dmrr.592

Document status and date:

Published: 01/01/2006

DOI:

10.1002/dmrr.592

Document Version:

Publisher's PDF, also known as Version of record

Document license:

Taverne

\section{Please check the document version of this publication:}

- A submitted manuscript is the version of the article upon submission and before peer-review. There can be important differences between the submitted version and the official published version of record.

People interested in the research are advised to contact the author for the final version of the publication, or visit the DOI to the publisher's website.

- The final author version and the galley proof are versions of the publication after peer review.

- The final published version features the final layout of the paper including the volume, issue and page numbers.

Link to publication

\footnotetext{
General rights rights.

- You may freely distribute the URL identifying the publication in the public portal. please follow below link for the End User Agreement:

www.umlib.nl/taverne-license

Take down policy

If you believe that this document breaches copyright please contact us at:

repository@maastrichtuniversity.nl

providing details and we will investigate your claim.
}

Copyright and moral rights for the publications made accessible in the public portal are retained by the authors and/or other copyright owners and it is a condition of accessing publications that users recognise and abide by the legal requirements associated with these

- Users may download and print one copy of any publication from the public portal for the purpose of private study or research.

- You may not further distribute the material or use it for any profit-making activity or commercial gain

If the publication is distributed under the terms of Article $25 \mathrm{fa}$ of the Dutch Copyright Act, indicated by the "Taverne" license above, 


\section{The effect of the PPAR $y$ ligand rosiglitazone on energy balance regulation}

\author{
Annemiek M. C. P. Joosen ${ }^{1 *}$ \\ Arjen H. F. Bakker ${ }^{2}$ \\ Maarten J. A. Gering ${ }^{1}$ \\ Klaas R. Westerterp ${ }^{1}$ \\ ${ }^{1}$ Department of Human Biology, \\ Maastricht University, Maastricht, \\ The Netherlands \\ ${ }^{2}$ Department of Molecular Genetics, \\ Maastricht University, Maastricht, \\ The Netherlands \\ *Correspondence to: Annemiek M. \\ C. P. Joosen, Department of Human \\ Biology, Maastricht University, P.O. \\ Box 616, 6200 MD Maastricht, The \\ Netherlands. \\ E-mail: A.Joosen@HB.Unimaas.NL
}

\begin{abstract}
Background and aim Fat mass generation requires an energy surplus and the activity of the peroxisome proliferator-activated receptor $\gamma$ (PPAR $\gamma$ ). We investigated if the PPAR $\gamma$ ligand rosiglitazone influences substrate usage, energy expenditure (EE) and energy intake (EI) and, thereby, how PPAR $\gamma$ activity contributes to susceptibility to obesity.
\end{abstract}

Methods Twenty healthy males (20-29 years) were randomly assigned to receive a placebo $(n=10)$ or rosiglitazone $(8 \mathrm{mg} / \mathrm{d})(n=10)$ for seven consecutive days, while staying in a respiration chamber. Food intake was ad libitum. Body composition was determined by underwater weighing (day 1) and deuterium dilution (day 1 and 8).

Results Mean $( \pm \mathrm{SE})$ EI was $15.9 \pm 0.9 \mathrm{MJ} / \mathrm{d}$ in the placebo group and $18.9 \pm 1.2 \mathrm{MJ} / \mathrm{d}$ in the rosiglitazone group. Mean EE was $11.3 \pm 0.3 \mathrm{MJ} / \mathrm{d}$ and $12.5 \pm 0.5 \mathrm{MJ} / \mathrm{d}$ for the placebo and rosiglitazone groups respectively. This resulted in a cumulative positive energy balance (EB) of $32.3 \pm 5.1 \mathrm{MJ}$ for placebo and $44.7 \pm 6.9 \mathrm{MJ}$ for rosiglitazone. There were no significant differences in EI, EE, and EB between treatments. Both groups did not adjust their fat oxidation to the increased fat intake, but fat oxidation decreased faster in the rosiglitazone group (significantly lower on days 6 and 7). During treatment with rosiglitazone, significantly more fat storage was seen in overweight subjects while this was not the case in the placebo group.

Conclusions Our results suggest a shift in substrate usage during PPAR $\gamma$ stimulation leading to a preference for fat storage, especially in subjects with a higher BMI. Copyright (c) 2005 John Wiley \& Sons, Ltd.

Keywords peroxisome proliferator-activated receptor $\gamma$; substrate usage; energy expenditure; energy intake; energy storage; humans

\section{Introduction}

Obesity develops when energy intake (EI) exceeds energy expenditure (EE) for longer periods. Excess energy is stored in the main energy storing tissue, the adipose tissue. The adipocyte is not only an important mediator of energy metabolism by storing excess energy as fat, but also by secreting adipokines involved in energy metabolism, like leptin, adiponectin and resistin [1]. Fat mass generation requires an energy surplus and the activity of the peroxisome proliferator-activated receptor $\gamma(\operatorname{PPAR} \gamma)$, a transcription factor that is expressed at high levels in adipose tissue, and at lower levels in the skeletal muscle, liver and heart [2,3]. Dominant-negative PPAR $\gamma$ mutations lead to partial lipodystrophy [4], while dominant-positive PPAR $\gamma$ mutations 
are associated with severe obesity [5]. PPAR $\gamma$ is a key factor in fat metabolism as it is required for adipogenesis, the differentiation of preadipocytes into mature adipocytes, and has an important role in fat storage [6]. PPAR $\gamma$ is a member of the nuclear hormone receptor family whose transcriptional activity is regulated by the formation of heterodimers and the binding of ligands [7]. Natural ligands include polyunsaturated fatty acids and eicosanoids [8]. Potent synthetic ligands include the anti-diabetic thiazolidinedione (TZD) class of drugs [9]. TZDs are widely and effectively used in the treatment of type 2 diabetes mellitus for their insulin-sensitizing effects [9]. However, treatment with TZD is accompanied by weight gain in rodents [10] and obese, diabetic patients [11]. Though fluid retention is a known side effect of TZD treatment [12], the major part of the weight gain consists of fat [10] which does suggest an effect of PPAR $\gamma$ on energy balance (EB) regulation as fat gain will only occur in the presence of an energy surplus. Indeed, PPAR $\gamma$ activation in lean rats, in diet-induced obese rats, and in insulin-resistant fatty Zucker rats resulted in weight gain because of both an increased food intake and an improved feed efficiency [13-15]. On the other hand, pair-feeding of chow-fed rats and dietary obese rats to prevent hyperphagia prevented rosiglitazone-related weight gain in chow-fed rats, though this was not the case with the dietary obese rats [13]. Similar results were observed in humans. Obese, diabetic patients treated with TZD, who reported weight gain following TZD treatment, effectively lost weight with caloric restriction and increased physical activity [11]. These observations emphasize a possible role for PPAR $\gamma$ in the regulation of EI and expenditure. We hypothesized that stimulation of $\operatorname{PPAR} \gamma$ with the PPAR $\gamma$ ligand rosiglitazone in healthy, normal to overweight men would induce susceptibility to weight gain by affecting substrate usage, EE and EI.

\section{Subjects and methods}

\section{Subjects}

Subjects were recruited through noticeboards in the university and in the university hospital. Subjects had to be male, between the age of 18 and 40 years, Caucasian, healthy and have a body mass index (BMI) between 20 and $32 \mathrm{~kg} / \mathrm{m}^{2}$. They had to be unrestrained eaters, as indicated by the Three-Factor Eating Questionnaire [16] with scores $\leq 9$ on Factor 1 (cognitive restraint). Subjects completed a medical questionnaire before entering the study; only subjects in good health were included. Subjects who followed a dietary regime with the aim to lose or gain weight within a year prior to the study were excluded. The study design required that the subjects were not fully informed about the adipogenic effect of the PPAR $\gamma$ agonist rosiglitazone as this could influence selfselected food and EI and activity-induced EE. Therefore, subjects were told that they would receive either a substance that influences fat metabolism or a non-active
Table 1. Baseline characteristics of the subjects

\begin{tabular}{lcclll}
\hline & \multicolumn{2}{c}{ Placebo $(n=10)$} & & \multicolumn{2}{l}{ Rosiglitazone $(n=10)$} \\
\cline { 2 - 3 } \cline { 6 - 7 } & Mean & SE & & Mean & SE \\
\hline Age (years) & 22 & 1 & & 24 & 1 \\
Height $(\mathrm{m})$ & 1.83 & 0.02 & & 1.84 & 0.02 \\
Body weight $(\mathrm{kg})$ & 80.2 & 3.5 & & 85.7 & 3.6 \\
BMl $\left(\mathrm{kg} / \mathrm{m}^{2}\right)$ & 24.0 & 1.3 & & 25.1 & 0.7 \\
Body fat $(\%)$ & 19.6 & 1.9 & & 20.3 & 2.4 \\
Cognitive restraint score $^{\mathrm{a}}$ & 5 & 1 & & 4 & 1 \\
\hline
\end{tabular}

a Factor 1 of the three-factor eating questionnaire [16].

substance (placebo) in a double-blind manner (i.e. neither the subject nor the investigator knew what the subject received during the experiment). The study was approved by the Ethics Committee of Maastricht University. All subjects received verbal and written information and signed a written consent form. Twenty men between the age of 20 and 29 years participated in the study. Characteristics of the subjects are shown in Table 1.

\section{Experimental design}

Subjects were studied during a stay in a respiration chamber for seven consecutive days for EE and substrate oxidation measurements. Following a doubleblind, placebo-controlled design, subjects were randomly assigned to receive either $8 \mathrm{mg} / \mathrm{d}$ rosiglitazone (Avandia, GlaxoSmithKline BV, The Netherlands) or a placebo orally. Drugs were dosed twice daily for the total stay of 7 days in the respiration chamber. Subjects were asked to eat ad libitum from an excess of food supplied at each mealtime and as snacks. No exercise protocol was imposed, but sleeping during daytime and strenuous physical activity were not allowed. Subjects were woken up between 08:00 and 08:30 h, and they were free to choose their bedtime in the evening. Body composition was determined by underwater weighing and deuterium dilution (day 1) or by deuterium dilution alone (day 8). On the same days, blood samples were taken.

\section{Dietary intake}

Meals consisting of typically Dutch food items were provided three times per day, breakfast between $08: 30$ and $09: 00 \mathrm{~h}$, lunch between $12: 30$ and $13: 00 \mathrm{~h}$, and dinner between 18:00 and 18:30 h. Breakfast and lunch consisted of bread, savoury and sweet condiments, fruit, yogurt, milk, fruit juice, instant coffee (decaffeinated) and tea. For dinner, subjects could choose between ready-prepared potato-, pasta- or rice-based meals with only vegetables or with vegetables plus meat or fish. They were allowed two alcoholic consumptions, white or red wine or beer, per day. A wide variety of snacks was continuously available in the chamber in packages that were refreshed every morning. Snacks consisted of savoury items (crisps, nuts), sweet items (chocolate bars, 
sweets), various biscuits, fruit (apple, orange, banana), instant soup, fruit juice, instant coffee (decaffeinated) and tea. Meals and snacks were supplied in excess to be eaten ad libitum; extra food items were readily available on request. All foods and drinks entering and leaving the respiration chamber were weighed to the nearest gram. Energy content and macronutrient composition of the diets were calculated using the Dutch food composition table (NEVO 1996).

\section{Procedures}

\section{Anthropometry and body composition}

Measurements were carried out in the morning after voiding and before breakfast. Body weight and height were measured to the nearest $0.01 \mathrm{~kg}$ and $0.1 \mathrm{~cm}$ respectively. Body mass index (BMI, $\mathrm{kg} / \mathrm{m}^{2}$ ) was calculated as body weight $(\mathrm{kg})$ divided by height (m) squared. Body density was determined by underwater weighing with simultaneous measurement of residual lung volume with the helium dilution technique. Total body water (TBW) was determined with deuterium dilution following the Maastricht protocol [17]. Body composition was calculated from body density and TBW using the three-compartment model of Siri [18].

\section{Energy expenditure}

EE was measured in the respiration chamber [19] from oxygen consumption, carbon dioxide production and urinary nitrogen excretion according to the formula of Brouwer [20]. The respiration chamber measured $14 \mathrm{~m}^{3}$ and was furnished with a bed, chair, table, TV, radio, telephone, computer, washbowl and toilet facilities [19].

\section{Substrate oxidation}

Carbohydrate ( $\mathrm{CHO})$, fat $(\mathrm{F})$ and protein $(\mathrm{P})$ oxidation was calculated from oxygen consumption, carbon dioxide production and urinary nitrogen excretion. As subjects were allowed to have maximally two alcoholic consumptions per day, oxygen consumption and carbon dioxide production on these days were first corrected for alcohol intake, assuming that all alcohol ingested was oxidized, before calculation of $\mathrm{CHO}, \mathrm{F}$ and $\mathrm{P}$ oxidation according to the formula of Brouwer [20].

$$
\begin{aligned}
\text { P oxidation }(\mathrm{g} / \mathrm{d})= & 6.25 * \mathrm{~N} \\
\text { F oxidation }(\mathrm{g} / \mathrm{d})= & 1.718 * \mathrm{VO}_{2}-1.718 * \mathrm{VCO}_{2} \\
& -0.315 * \mathrm{P} \\
\text { CHO oxidation }(\mathrm{g} / \mathrm{d})= & 4.17 * \mathrm{VCO}_{2}-2.965 * \mathrm{VO}_{2} \\
& -0.390 * \mathrm{P}
\end{aligned}
$$

with:

$N=$ total nitrogen excreted in urine $(\mathrm{g} / \mathrm{d})$

$V O_{2}=$ oxygen consumption $(\mathrm{l} / \mathrm{d})$, corrected for alcohol intake

$V C O_{2}=$ carbon dioxide production $(\mathrm{l} / \mathrm{d})$, corrected for alcohol oxidation

$P=$ protein oxidation $(\mathrm{g} / \mathrm{d})$

24-h urine was collected from the second voiding of the day until the first voiding of the following day. 24-h urines were collected for each of the 7 days in the respiration chamber separately. Urine bottles contained $10 \mathrm{ml} \mathrm{H}_{2} \mathrm{SO}_{4}$ to prevent nitrogen loss through evaporation. Volume and nitrogen concentration were measured, the latter using a nitrogen analyser (Elemental Analyser, CHN-O-Rapid, Heraeus).

Carbohydrate and fat balances were calculated as intake minus oxidation of each macronutrient. The protein balance was calculated as [ $\mathrm{N}$ intake - (urinary $\mathrm{N}+$ faecal $\mathrm{N})] * 6.25$, assuming an average daily value of $3 \mathrm{~g} / \mathrm{d}$ for faecal $\mathrm{N}$ loss [21].

\section{Blood parameters}

After an overnight fast, blood samples were obtained and mixed with citrate to prevent clotting. Plasma was obtained by centrifugation $\left(4^{\circ} \mathrm{C}, 3000 \mathrm{rpm}, 10 \mathrm{~min}\right)$, frozen in liquid nitrogen and stored at $-80^{\circ} \mathrm{C}$ until analysis of concentrations of glucose (hexokinase method, Glucose HK 125 kit, ABX Diagnostics, Montpellier, France), insulin (ELISA, Mercodia, Uppsala, Sweden), leptin (double-antibody RIA, human leptin specific RIA kit, Linco Research Inc., St Charles, USA) and triacylglycerols (TAGs) (Triglycerides liquicolor kit, Instruchemie, Delfzijl, The Netherlands).

\section{Statistical analysis}

Results are presented as mean \pm standard error (SE). Differences between treatments were analysed with oneway analysis of variance (ANOVA) or the Mann-Whitney U-test (blood parameters). Interaction between treatment and body weight class for fat balance was analysed with an univariate ANOVA with treatment and body weight class as fixed factors. Measurements at baseline and at the end of the experiment were compared with Student's paired t-test (two-tailed) or Wilcoxon's paired signed rank test (blood parameters). $P<0.05$ was considered statistically significant. SPSS 11 for Macintosh (SPSS Inc., Chicago, IL, 2002) was used for the analysis.

\section{Results}

\section{Energy intake and expenditure}

The mean daily EI was $15.9 \pm 0.9 \mathrm{MJ} / \mathrm{d}$ for placebo and $18.9 \pm 1.2 \mathrm{MJ} / \mathrm{d}$ for rosiglitazone, which was not significantly different $(P=0.06)$. Mean daily macronutrient 
composition was not significantly different between treatments, except for $\mathrm{CHO}$ intake, which was higher in the rosiglitazone group $(P<0.05)$.

Similar results were obtained for EE and macronutrient oxidation. EE was not significantly different between treatments $(P=0.09)$ with mean daily values of $11.3 \pm 0.3 \mathrm{MJ} / \mathrm{d}$ for placebo and $12.5 \pm 0.5 \mathrm{MJ} / \mathrm{d}$ for rosiglitazone. Mean daily macronutrient oxidation was not significantly different between treatments, except for $\mathrm{CHO}$ oxidation, which was higher in the rosiglitazone group $(P<0.05)$.

\section{Energy balance}

Energy balance (EB) was calculated as the difference between EI and EE. Figure 1 shows that cumulative EB increased from day 1 to day 7 on both treatments. By the end of day 7, cumulative EB was $32.3 \pm 5.1 \mathrm{MJ}$ for placebo and $44.7 \pm 6.9 \mathrm{MJ}$ for rosiglitazone. This differed significantly from zero on both treatments $(P<0.001)$, but was not significantly different between treatments $(P=0.16)$. The positive EB was reflected in changes in body weight. Body weight increased by $1.39 \pm 0.37 \mathrm{~kg}(P<0.01)$ in the placebo group and by $2.54 \pm 0.53 \mathrm{~kg}(P=0.001)$ in the rosiglitazone group. Changes in body weight did not differ significantly between treatments $(P=0.09)$. However, body weight change on rosiglitazone was associated with an increase in TBW of $1.6 \pm 0.61(P<0.05)$, whereas TBW did not significantly change in the placebo group $(-0.2 \pm 0.71$, $P=0.79)$. The difference in TBW change was not significantly different between treatments $(P=0.06)$.

The cumulative nutrient balances are shown in Figures 2(a),(b) and (c). The cumulative protein balance became more positive from day 1 to 7 in both groups (Figure 2a). Total protein balance by the end of day 7 was significantly different from zero for rosiglitazone $(1.6 \pm$ $0.5 \mathrm{MJ} ; P<0.01)$, but not for placebo $(1.0 \pm 0.6 \mathrm{MJ}$; $P=0.10)$. Total protein balance was not significantly different between treatments $(P=0.47)$.

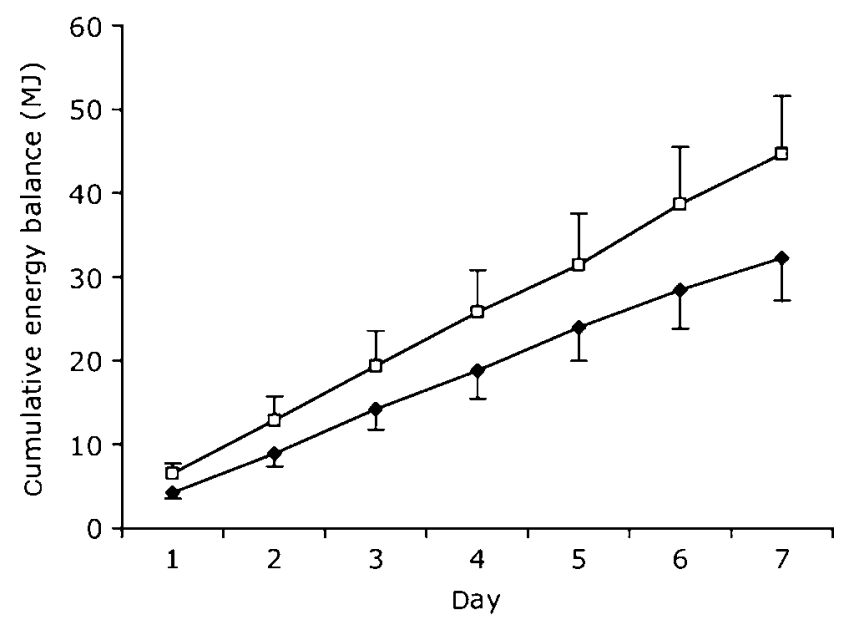

Figure 1. Mean ( \pm SE) cumulative energy balance (MJ) for the placebo $(\diamond)$ and rosiglitazone $(\square)$ groups on days 1-7
From day 1 to 4 the cumulative carbohydrate balance increased, but then decreased from day 5 indicating an adaptation of carbohydrate oxidation to carbohydrate intake (Figure 2b). By the end of day 7, total carbohydrate balance was not significantly different from zero for both the placebo $(0.8 \pm 1.8 \mathrm{MJ}, P=0.65)$ and the rosiglitazone groups $(-0.2 \pm 1.5 \mathrm{MJ}, P=0.90)$. There was no significant effect of treatment on the carbohydrate balance $(P=0.67)$.

The total EB was for both treatments mainly determined by the fat balance. The cumulative fat balance gradually increased from day 1 to 7 (Figure 2c). By the end of day 7 , the cumulative fat balance was $29.5 \pm 4.9 \mathrm{MJ}$ $(P<0.001)$ for placebo and $42.3 \pm 6.8 \mathrm{MJ}(P=0.00)$ for rosiglitazone. Although this was not significantly different between the treatments $(P=0.14)$, the pattern of fat intake and fat oxidation differed. Figure 3 shows that both groups did not adjust their fat oxidation to the increased fat intake. However, fat oxidation decreased faster in the rosiglitazone group and by day 6 and 7, fat oxidation was significantly lower compared to placebo.

Individual fat balances all increased similarly in the placebo group, independent of the classification normal weight (BMI $<25 \mathrm{~kg} / \mathrm{m}^{2}$, solid lines) or overweight (BMI $\geq 25 \mathrm{~kg} / \mathrm{m}^{2}$, dotted lines) (Figure $4 \mathrm{a}$ ). However, there was a significant interaction between body weight class and treatment $(P<0.001)$. As can be seen in Figure 4(b), during treatment with rosiglitazone overweight subjects stored more fat than normal weight subjects.

\section{Blood parameters}

Table 2 shows the mean fasting plasma concentrations of glucose, insulin, leptin and TAGs. In the placebo group, plasma glucose was decreased and TAGs were increased after overfeeding, other parameters did not change significantly. In the rosiglitazone group, plasma insulin and TAGs were increased after overfeeding, plasma glucose and leptin did not change significantly. There was a significant treatment effect on changes in plasma glucose $(P=0.02)$ and TAGs $(P=0.03)$, but not on plasma insulin $(P=0.07)$ and leptin $(P=0.15)$.

Table 2. Fasting plasma parameters at baseline and after self-induced overfeeding for the placebo and rosiglitazone treated groups

\begin{tabular}{|c|c|c|c|c|c|c|c|c|}
\hline & \multicolumn{4}{|c|}{ Placebo $(n=10)$} & \multicolumn{4}{|c|}{ Rosiglitazone $(n=10)$} \\
\hline & \multicolumn{2}{|c|}{ Baseline } & \multicolumn{2}{|c|}{ Overfeeding } & \multicolumn{2}{|c|}{ Baseline } & \multicolumn{2}{|c|}{ Overfeeding } \\
\hline & mean & SE & mean & SE & mean & SE & mean & SE \\
\hline Glucose $(\mathrm{mmol} / \mathrm{l})$ & 5.0 & 0.1 & $4.6^{a}$ & 0.1 & 4.8 & 0.1 & 4.9 & 0.2 \\
\hline Insulin $(\mu \mathrm{U} / \mathrm{ml})$ & 7.8 & 0.6 & 8.5 & 0.5 & 6.0 & 0.8 & $8.2^{b}$ & 1.1 \\
\hline Leptin ( $\mathrm{ng} / \mathrm{ml})$ & 5.4 & 1.1 & 5.6 & 1.0 & 5.6 & 1.4 & 5.3 & 1.4 \\
\hline $\mathrm{TAG}(\mathrm{mmol} / \mathrm{l})$ & 0.6 & 0.04 & $1.2^{\mathrm{a}}$ & 0.2 & 0.8 & 0.1 & $2.5^{a}$ & 0.7 \\
\hline
\end{tabular}

$\mathrm{TAG}=$ triacylglycerol

aSignificantly different from baseline (within-group) using Wilcoxon's paired signed rank test $P<0.01$.

${ }^{b} P=0.01$. 

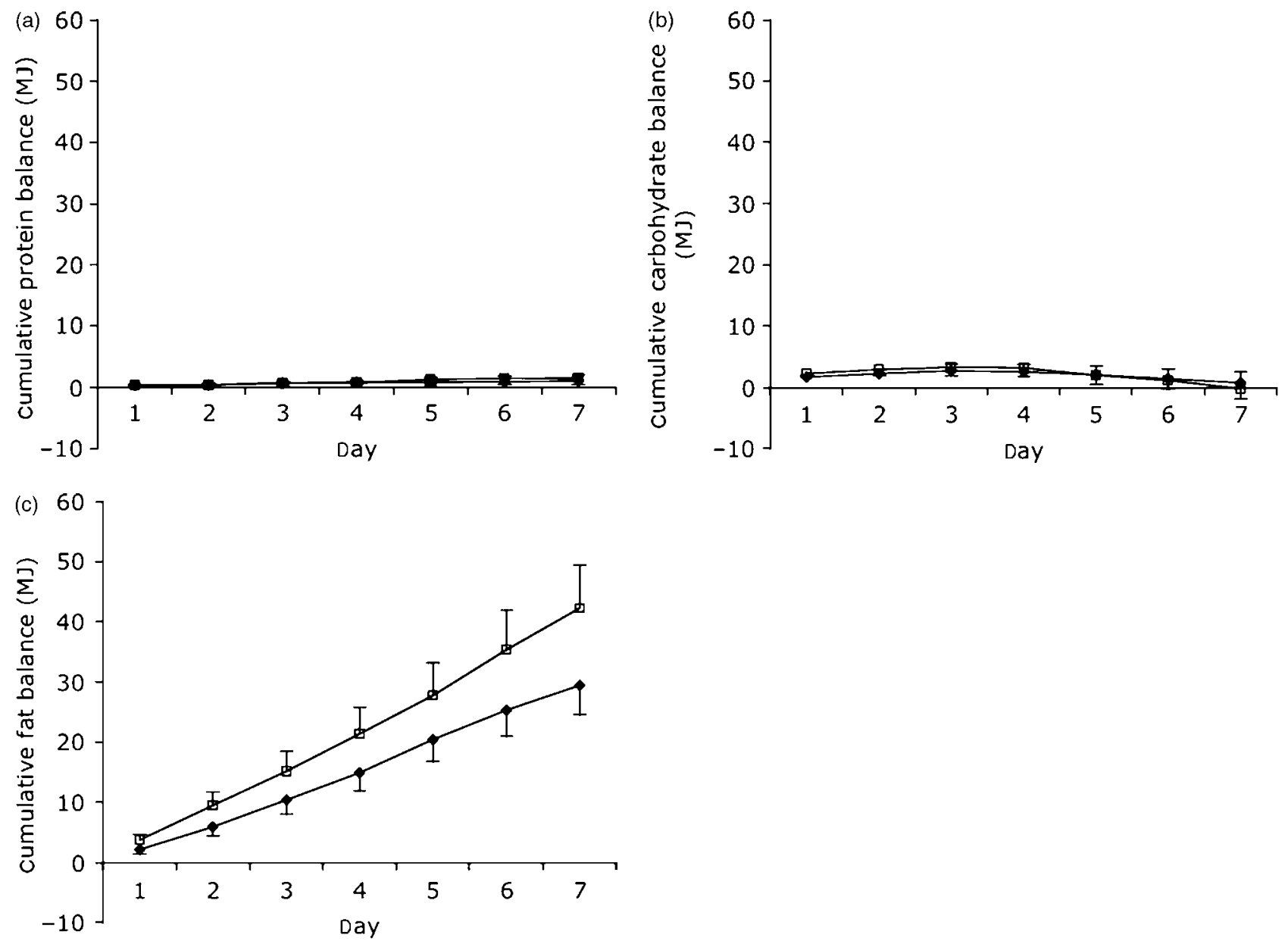

Figure 2. Mean ( \pm SE) cumulative protein (a), carbohydrate (b) and fat (c) balances (MJ) for the placebo ( $\downarrow)$ and rosiglitazone ( $\square$ ) groups on days 1-7

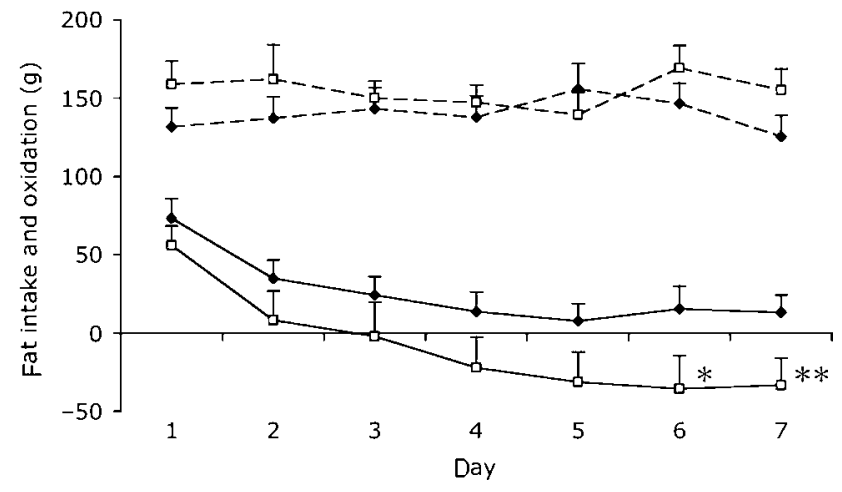

Figure 3. Mean $( \pm S E)$ fat intake (dotted lines) and fat oxidation (solid lines) (g) for placebo $(\diamond)$ and rosiglitazone $(\square)$ groups on days $1-7 .{ }^{*} P=0.05,{ }^{* *} P<0.05$ oxidation between groups (one-way ANOVA)

\section{Discussion}

The increasing prevalence of obesity is related to changing dietary habits and a sedentary lifestyle [22]. The contribution of environmental factors is apparent, but genetic factors are also involved [23]. PPAR $\gamma$ is a key regulator of fat metabolism; therefore, a high PPAR $\gamma$ activity could form a predisposing factor for the excess of fat mass characteristic for obesity. The present study aimed to investigate the influence of the PPAR $\gamma$ ligand rosiglitazone on substrate usage, EE and EI. Twenty males were studied during a 7-day stay in the respiration chamber. During this period, PPAR $\gamma$ activity was stimulated with rosiglitazone in ten males; the control group received a placebo treatment.

As shown before [24,25], the sedentary lifestyle imposed by the restrictions of the small environment in the respiration chamber together with an ad libitum food intake resulted in a significant positive EB by the end of day 7 in both groups. Though not statistically significant, there was a trend towards an effect of PPAR $\gamma$ stimulation on EB regulation. EI tended to be higher in the rosiglitazone treated group, similar to results observed in lean rats, in diet-induced obese rats, and in insulinresistant fatty Zucker rats treated with TZD, where an increased weight gain was associated with increased food intake and feed efficiency [13-15]. Theoretically, PPAR $\gamma$ can influence food intake through a direct effect on the central nervous system or indirectly through effects on peripheral tissues. In humans, PPAR $\gamma$ is most abundantly expressed in adipose tissue and at lower levels in skeletal muscle, liver and heart [2,3]. It is therefore most likely that the tendency to increase food intake with 

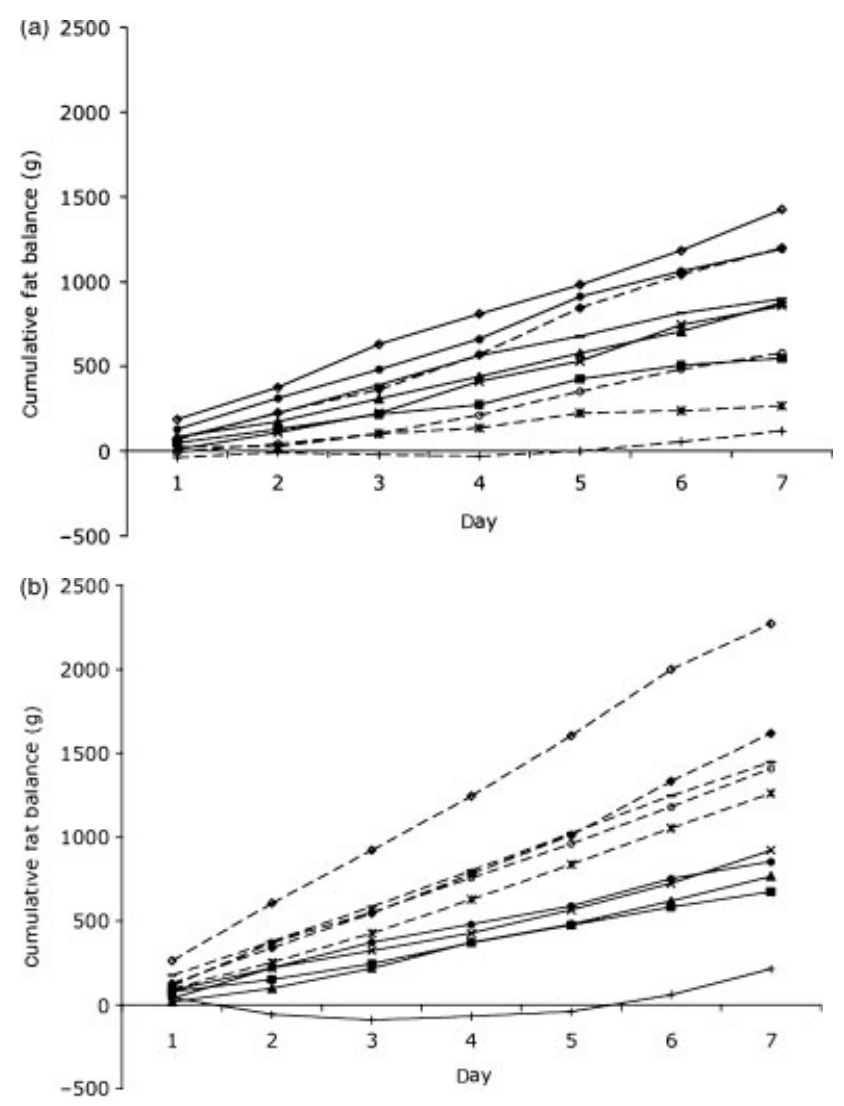

Figure 4. Individual cumulative fat balances (g) for the placebo (a) and rosiglitazone (b) groups. Solid lines represent subjects with $\mathrm{BMI}<25 \mathrm{~kg} / \mathrm{m}^{2}$, dotted lines represent subjects with BMI $\geq 25 \mathrm{~kg} / \mathrm{m}^{2}$

rosiglitazone is because of the PPAR $\gamma$ activity in adipose tissue. The adipokine leptin is known to be a regulator of EI and expenditure [1], and plasma leptin concentrations can be decreased in lean and diet-induced rats with PPAR $\gamma$ stimulation [13]. However, plasma leptin was not decreased in ad libitum-fed rats treated with rosiglitazone and could thus not explain the observed hyperphagia [13]. Similarly, plasma leptin did not change on either treatment and is therefore unlikely to have influenced food intake or thermogenesis in our subjects.

There was no statistical significant effect of PPAR $\gamma$ stimulation on EE, indicating no thermogenic dissipation of the excess energy. However, when we look at nutrient oxidation, there was an effect on fat oxidation after 6 days of rosiglitazone treatment. Both groups could not adjust their fat oxidation to fat intake during the 7-day treatment period, but treatment with rosiglitazone worsened the adaptation of fat oxidation to fat intake. Independent of treatment, the majority of excess energy was stored as fat, as can be expected from the limited storage capacity for carbohydrates which forces an increase in carbohydrate oxidation to maintain carbohydrate balance. In addition, the positive fat balances seen in the majority of the subjects developed faster in overweight subjects compared to normal weight subjects treated with rosiglitazone. Smith et al. [26] found similar results in obese type 2 diabetic patients treated with another TZD, pioglitazone (45 mg/d), for 24 weeks. Though not statistically significant, substrate oxidation after a meal tended towards fat storage and an increased carbohydrate oxidation. Pioglitazone treatment resulted in fat gain, but this change could not be accounted for, as measurements of 24-h EE and EI were not included. In contrast, Füllert et al. [27] did not find an increase in body weight in overweight, non-diabetic patients with arterial hypertension treated with $45 \mathrm{mg} / \mathrm{d}$ pioglitazone for 16 weeks.

Furthermore, overfeeding resulted in increased fasting plasma TAG concentrations in both groups, but this increase was significantly higher with PPAR $\gamma$ stimulation. As fasting plasma TAGs and fat oxidation have been shown to predict weight gain in diet-induced prone and resistant rats [28], this indicates an insufficient fat oxidation and a tendency to retain TAGs in the plasma until storage in the adipose tissue. However, PPAR $\gamma$ activation during ad libitum feeding, initiating a positive EB, resulted in lower plasma TAGs in $\mathrm{db} / \mathrm{db}$ mice, fatty Zucker rats [10], ob/ob mice [29] and diet-induced mice [14] but not in lean mice [29], which suggests that fat storage upon PPAR $\gamma$ activation is only accompanied by a decrease in plasma TAGs if baseline values are already elevated.

The favourable effects of TZD treatment on plasma glucose and insulin concentrations in type 2 diabetic patients are attributed to their ability to stimulate PPAR $\gamma$ [9]. However, in our group of healthy, normal to overweight men, overfeeding induced a significant increase in plasmainsulin concentrations with PPAR $\gamma$ stimulation. Probably, TZD treatment is only associated with decreased insulin in patients already showing elevated plasma concentrations. This was also seen in patients with type 1 diabetes, where the greatest improvements in glycemic control with combined rosiglitazone and insulin treatment were seen in those patients with more pronounced markers of insulin resistance [30].

Though PPAR $\gamma$ activity in adipose tissue is necessary to convert an energy surplus into fat mass, PPAR $\gamma$ does play an important role in liver and muscle fat metabolism as well. Adipose-specific PPAR $\gamma$ knockout mice are lipodystrophic, leading to decreased plasma leptin and increased plasma TAG concentrations, storage of fat in skeletal muscle and liver, and increased hepatic PPAR $\gamma$ mRNA [31]. Hepatic PPAR $\gamma$ plays a critical role in the regulation of TAG content, blood glucose homeostasis and insulin resistance as liver-specific PPAR $\gamma$ knockout mice have a diabetic phenotype including an increased adiposity $[32,33]$. PPAR $\gamma$ knockout in muscle, the major site of fat oxidation, causes an impaired ability of muscle to use fat and thus shunting of fat to the liver, increased adiposity and hepatic insulin resistance. Our results indicate that healthy men treated with rosiglitazone develop an insulin-resistant state, with increased plasma TAG and insulin concentrations, which facilitates the development of a positive fat balance. The observation that overweight subjects develop a positive fat balance faster than do normal weight subjects supports this hypothesis, as overweight subjects are generally 
considered to be obesity-prone. We expect that these effects will be more pronounced when rosiglitazone treatment continues for longer periods as it might take more than 7 days for full effects on plasma parameters to develop. In addition, fat oxidation gradually became more suppressed compared to the placebo group from day 6 , which might have been earlier if rosiglitazone treatment was already started before the respiration chamber measurements. Yet, TBW was significantly increased in the rosiglitazone group, which indicates that rosiglitazone exerted effects on metabolism within 7 days.

In summary, our results suggest a shift in substrate usage during PPAR $\gamma$ stimulation leading to a preference for fat storage, especially in subjects with a higher BMI.

\section{Acknowledgements}

We thank Paul Schoffelen for technical assistance with the respiration chambers, Wendy Sluijsmans for nitrogen analyses and Sander Kersten for TAG analyses.

\section{References}

1. Rajala MW, Scherer PE. Minireview: the adipocyte-at the crossroads of energy homeostasis, inflammation, and atherosclerosis. Endocrinology 2003; 144: 3765-3773.

2. Mukherjee R, Jow L, Croston GE, Paterniti JR Jr. Identification, characterization, and tissue distribution of human peroxisome proliferator-activated receptor (PPAR) isoforms PPAR $\gamma 2$ versus $\operatorname{PPAR} \gamma 1$ and activation with retinoid $\mathrm{X}$ receptor agonists and antagonists. $J$ Biol Chem 1997; 272: 8071-8076.

3. Vidal-Puig AJ, Considine RV, Jimenez-Linan M, et al. Peroxisome proliferator-activated receptor gene expression in human tissues. J Clin Invest 1997; 99: 2416-2422.

4. Savage DB, Tan GD, Acerini CL, et al. Human metabolic syndrome resulting from dominant-negative mutations in the nuclear receptor peroxisome proliferator-activated receptor- $\gamma$. Diabetes 2003; 52: 910-917.

5. Ristow M, Muller-Wieland D, Pfeiffer A, Krone W, Kahn CR. Obesity associated with a mutation in a genetic regulator of adipocyte differentiation. $N$ Engl J Med 1998; 339: 953-959.

6. Rosen ED, Sarraf P, Troy AE, et al. PPAR $\gamma$ is required for the differentiation of adipose tissue in vivo and in vitro. Mol Cell 1999; 4: 611-617.

7. Rosen ED, Walkey CJ, Puigserver P, Spiegelman BM. Transcriptional regulation of adipogenesis. Genes Dev 2000; 14: 1293-1307.

8. Kliewer SA, Sundseth SS, Jones SA, et al. Fatty acids and eicosanoids regulate gene expression through direct interactions with peroxisome proliferator-activated receptors $\alpha$ and $\gamma$. Proc Natl Acad Sci U S A 1997; 94: 4318-4323.

9. Lehmann JM, Moore LB, Smith-Oliver TA, Wilkison WO, Willson TM, Kliewer SA. An antidiabetic thiazolidinedione is a high affinity ligand for peroxisome proliferatoractivated receptor $\gamma(\operatorname{PPAR} \gamma)$. J Biol Chem 1995; 270: 12953-12956.

10. Chaput E, Saladin R, Silvestre M, Edgar AD. Fenofibrate and rosiglitazone lower serum triglycerides with opposing effects on body weight. Biochem Biophys Res Commun 2000; 271: 445-450.

11. Asnani S, Richard BC, Desouza C, Fonseca V. Is weight loss possible in patients treated with thiazolidinediones? Experience with a low-calorie diet. Curr Med Res Opin 2003; 19: 609-613.
12. Lebovitz HE. Differentiating members of the thiazolidinedione class: a focus on safety. Diabetes Metab Res Rev 2002; 18(Suppl. 2): S23-S29.

13. Pickavance LC, Buckingham RE, Wilding JP. Insulin-sensitizing action of rosiglitazone is enhanced by preventing hyperphagia. Diabetes Obes Metab 2001; 3: 171-180.

14. Larsen PJ, Jensen PB, Sorensen RV, et al. Differential influences of peroxisome proliferator-activated receptors $\gamma$ and $-\alpha$ on food intake and energy homeostasis. Diabetes 2003; 52: 2249-2259.

15. Wang $\mathrm{Q}$, Dryden S, Frankish HM, et al. Increased feeding in fatty Zucker rats by the thiazolidinedione BRL 49653 (rosiglitazone) and the possible involvement of leptin and hypothalamic neuropeptide Y. Br J Pharmacol 1997; 122: 1405-1410.

16. Stunkard AJ, Messick S. The three-factor eating questionnaire to measure dietary restraint, disinhibition and hunger. J Psychosom Res 1985; 29: 71-83.

17. Westerterp KR, Wouters L, van Marken Lichtenbelt WD. The Maastricht protocol for the measurement of body composition and energy expenditure with labeled water. Obes Res 1995; 3: 49-57.

18. Siri WE. Body composition from fluid spaces and density: analysis of methods 1961. Nutrition 1993; 9: 480-491; discussion 92.

19. Schoffelen PF, Westerterp KR, Saris WH, Ten Hoor F. A dualrespiration chamber system with automated calibration. J Appl Physiol 1997; 83: 2064-2072.

20. Brouwer E. On simple formulae for calculating the heat expenditure and the quantities of carbohydrate and fat oxidized in metabolism of men and animals, from gaseous exchange (Oxygen intake and carbonic acid output) and urine-N. Acta Physiol Pharmacol Neerl 1957; 6: 795-802.

21. Lammert O, Grunnet N, Faber P, et al. Effects of isoenergetic overfeeding of either carbohydrate or fat in young men. $\mathrm{Br} \mathrm{J}$ Nutr 2000; 84: 233-245.

22. Weinsier RL, Hunter GR, Heini AF, Goran MI, Sell SM. The etiology of obesity: relative contribution of metabolic factors, diet, and physical activity. Am J Med 1998; 105: 145-150.

23. Bouchard C. Heredity and the path to overweight and obesity. Med Sci Sports Exerc 1991; 23: 285-291.

24. Larson DE, Rising R, Ferraro RT, Ravussin E. Spontaneous overfeeding with a 'cafeteria diet' in men: effects on 24- hour energy expenditure and substrate oxidation. Int $J$ Obes Relat Metab Disord 1995; 19: 331-337.

25. Murgatroyd PR, Goldberg GR, Leahy FE, Gilsenan MB, Prentice AM. Effects of inactivity and diet composition on human energy balance. Int $J$ Obes Relat Metab Disord 1999; 23: 1269-1275.

26. Smith SR, De Jonge L, Volaufova J, Li Y, Xie H, Bray GA. Effect of pioglitazone on body composition and energy expenditure: a randomized controlled trial. Metabolism 2005; 54: 24-32.

27. Fullert S, Schneider F, Haak E, et al. Effects of pioglitazone in nondiabetic patients with arterial hypertension: a double-blind, placebo-controlled study. J Clin Endocrinol Metab 2002; 87: 5503-5506.

28. Ji H, Friedman MI. Fasting plasma triglyceride levels and fat oxidation predict dietary obesity in rats. Physiol Behav 2003; 78: 767-772.

29. Sell H, Berger JP, Samson P, et al. PPAR $\gamma$ agonism increases the capacity for sympathetically-mediated thermogenesis in lean and ob/ob mice. Endocrinology 2004; 145: 3925-3934.

30. Strowig SM, Raskin P. The effect of rosiglitazone on overweight subjects with type 1 diabetes. Diabetes Care 2005; 28: $1562-1567$.

31. Jones JR, Barrick C, Kim KA, et al. Deletion of PPAR $\gamma$ in adipose tissues of mice protects against high fat diet-induced obesity and insulin resistance. Proc Natl Acad Sci USA 2005; 102: 6207-6212.

32. Gavrilova O, Haluzik M, Matsusue K, et al. Liver peroxisome proliferator-activated receptor $\gamma$ contributes to hepatic steatosis, triglyceride clearance, and regulation of body fat mass. $J$ Biol Chem 2003; 278: 34268-34276.

33. Matsusue K, Haluzik M, Lambert G, et al. Liver-specific disruption of PPAR $\gamma$ in leptin-deficient mice improves fatty liver but aggravates diabetic phenotypes. J Clin Invest 2003; 111: 737-747. 